\title{
ANALYSIS OF MICROSTRUCTURE AND HARDNESS OF WELDED JOINTS OF DISSIMILAR STEEL OF AISI 1018 - AISI 304
}

\author{
Gilang Gumilar ${ }^{1}$ Imin Abdullah ${ }^{2}$, Rochim Suratman ${ }^{3}$ and Asep Ridwan Setiawan ${ }^{3}$ \\ ${ }^{1}$ Teknologi Rekayasa Pengelasan dan Fabrikasi, Fakultas Vokasi, Institut Teknologi dan Sains \\ Bandung, Jl. GaneshaBoulevard Kota Deltamas, Bekasi, 17530 \\ ${ }^{2}$ Teknik Metalurgi dan Material,Fakultas Teknik dan Desain, Institut Teknologi dan Sains \\ Bandung, Jl. GaneshaBoulevard Kota Deltamas, Bekasi, 17530 \\ ${ }^{3}$ Teknik Material,Fakultas Teknik Mesin dan Dirgantara, Institut Teknologi Bandung \\ Jl. GaneshaNo. 10, Bandung, 40132 \\ E-mail: gilang.gumilar@itsb.ac.id
}

Received: 2 April 2019 Revised: 10 June $2019 \quad$ Accepted: 14 June 2019

\begin{abstract}
ANALYSIS OF MICROSTRUCTURE AND HARDNESS OF WELDED JOINTS OF DISSIMILAR STEEL OF AISI 1018 - AISI 304. This research studies the microstructure and hardness property of shield metal arc welding (SMAW) from dissimilar metals between austenitic stainless steel (SS) AISI 304 and low carbon steel (LCS) AISI 1018 using E308 filler metal. The procedure used was LCS-to-LCS welding carried out without post weld heat treatment (PWHT) and SS-to-SS welding followed by PWHT at a temperature of 1000 ÚC and holding time for 12 minutes. Then, it was followed by shock cooling in aqueous media. The difference in PWHT stages in the two procedures is expected to affect the microstructure and hardness of the welding results. This was conducted to find out more precise procedures in the SMAW technique for welding dissimilar metals like AISI 304 with AISI 1018 so that the risk of chromium carbide precipitate formation and the low hardness of welded joints can be reduced. The results showed there were chromium carbide precipitates in the heat-affected zone (HAZ) of AISI 304, grain enlargement in the HAZ area of both steels, as well as the formation of the ferrite delta phase in the welding area by LCS-to-LCS welding. While the value of hardness in the HAZ area of AISI 304 has decreased, increases occur in the HAZ area of AISI 1018 in all welding conditions. In addition, PWHT treatment can increase the hardness on the AISI 1018 side due to the formation of the martensite phase, decrease in the hardness value on the AISI 304 side, and the reduced ferrite delta phase and the number of chromium carbide precipitates.
\end{abstract}

Keywords: Shield Metal Arc Welding (SMAW), Low carbon steel AISI 1018, Stainless steel AISI 304, Dissimilar welding.

\footnotetext{
ABSTRAK

ANALISA STRUKTUR MIKRO DAN KEKERASAN SAMBUNGAN LAS TAK SEJENIS BAJA AISI 1018 - AISI 304. Penelitian ini mempelajari struktur mikro dan sifat kekerasan hasil pengelasan shield metal arc welding (SMAW) logam tak sejenis antara baja tahan karat (BTK) austenitik AISI 304 dan baja karbon rendah (BKR) AISI 1018 dengan menggunakan logam pengisi E308. Prosedur yang digunakan adalah prosedur pengelasan BKR ke BKR yang dilakukan tanpa post weld heat treatment (PWHT) dan prosedur pengelasan BTK ke BTK yang dilanjutkan dengan PWHT pada suhu 1000 ÚC dan waktu penahanan selama 12 menit. Kemudian, dilanjutkan dengan pendinginan kejut dalam media air. Adanya perbedaan tahap PWHT pada kedua prosedur tersebut diharapkan berpengaruh pada struktur mikro dan kekerasan hasil pengelasan. Ini dilakukan untuk mengetahui prosedur yang lebih tepat pada teknik SMAW dalam pengelasan logam tak sejenis AISI 304 dengan AISI 1018 sehingga resiko terbentuknya presipitat kromium karbida dan rendahnya kekerasan sambungan las bisa dikurangi. Hasil penelitian menunjukkan terdapat presipitat kromium karbida di daerah heat-affected zone (HAZ) AISI 304, pembesaran butir di daerah HAZ kedua baja, serta terbentuknya fase delta
} 
ferit pada daerah las dengan prosedur pengelasan BKR ke BKR. Sementara nilai kekerasan di daerah HAZ AISI 304 mengalami penurunan, sedangkan di daerah HAZ AISI 1018 mengalami peningkatan disemua kondisi pengelasan. Selain itu, perlakuan PWHT dapat meningkatan kekerasan disisi AISI 1018 karena terbentuknya fase martensit, penurunan nilai kekerasan disisi AISI 304, serta berkurangnya fase delta ferit dan jumlah presipitat kromium karbida.

Kata kunci: Shield Metal Arc Welding (SMAW), Baja karbon rendah AISI 1018, Baja tahan karat AISI 304, Pengelasan tak sejenis.

\section{INTRODUCTION}

In the industrial world, dissimilar welding between austenitic stainless steel (SS) and low carbon steel (LCS) is widely used in industrial components, such as pressure vessels, boilers, heat exchangers in power plants, nuclear reactors, petrochemicals, as well as in the oil and gas industries $[1,2]$. The combination of both types of steel results in changes in physical and chemical properties in the joint area. The energy given during SS welding process with LCS can activate the formation of compounds consisting of the two alloying elements; consequently at the grain boundary chromium depletion occurs to less than $12 \%$ [3]. Usually, in these areas, chromium carbide precipitates and solidification cracking can be formed hence they may influ-ence corrosion resistance properties [2-5].

Several studies have been conducted to reduce the above issues by using different welding procedures. $\mathrm{Wu} \mathrm{W}$., et al. use laser beam welding (LBW) technique to combine SS and LCS, by comparing two different welding speeds, namely $12 \mathrm{~mm} / \mathrm{s}$ and $24 \mathrm{~mm} / \mathrm{s}$ [6]. This study shows that the greater the welding speed, the smaller the heat-affected zone (HAZ) on LCS and the highest hardness is in the welding area around the LCS side edge with weld metal (WM) (about $0.6 \mathrm{~mm}$ from the joint boundary on both sides), while the tensile strength is the same, but for greater elongation at a higher rate. Unfortunately, in dissimilar welding joints, a large corrosion current density arises due to the effect of galvanic corrosion [6]. Areas that have the potential to experience corrosion can be avoided by reducing chromium carbide production. This is what was conducted by Prabakaran, et al. namely by optimizing laser power parameters, welding speed, and focus distance on LBW techniques for dissimilar welding of SS (AISI 316) and LCS (AISI 1018) [1]. In this study, it is known that post weld heat treatment affects the quality of the mechanical properties of welded joints with the tensile strength reaching $475,112 \mathrm{MPa}$ at $960 \mathrm{oC}$ and can reduce the grain size and chromium carbide production. As a result, at such temperature, the sample exhibits high corrosion resistance. The parameters used are $2600 \mathrm{~W}$ laser power, $1.5 \mathrm{~m} / \mathrm{min}$ welding speed with a focus distance of $20 \mathrm{~mm}$ [1]. This study shows that with the proper procedures and parameters, mechanical strength and corrosion resistance can be improved.
Welding with LBW technique is still rarely used in in-dustries due to its high cost. In general, the welding pro-cess that is widely used is the shields metal arc welding (SMAW) technique [2]. This technique is used as it has several advantages; more flexible, lower production costs, and produce joints with strong metallic bonds [7]. However, in the study of dissimilar welding between SS (AISI 304) and LCS (AISI 1020) conducted by Wichan et al., it shows that this technique produces lower mechanical strength and corrosion resistance when compared to gas tungsten arc welding (GTAW) technique [2]. Similar to LBW welding technique, the mechanical strength and corrosion resistance of the results of dissimilar welding using SMAW technique can be improved by using the proper welding procedure.

Based on the Welding Procedure Specification (WPS), LCS and SS welding with SMAW technique has a different stage. In BKT welding with SMAW technique, there is a post weld heat treatment (PWHT) stage while none applies for LCS. Problems due to dissimilar welding with SMAW technique mentioned ear-lier are expected to be overcome by one of the welding pro-cedures. Therefore, the two welding procedures will be ap-plied to dissimilar welding of SS and LCS using SMAW technique in this study.

The microstructure and joints of dissimilar metal welds with both procedures above will be compared and analyzed to find out which welding procedure is better applied to dissimilar welding with SMAW technique so as to increase the strength of the welded joints and reduce the risk of corrosion. The types of steel that will be used in this study are AISI 304 and AISI 1018. Both types of steel were chosen as they are widely used. In addition, AISI 1018 is a low carbon steel that has good welding and mechanical properties and is easy to obtain. It's just that the weld is easy to crack and the toughness is reduced [5]. Meanwhile, AISI 304 is a stainless steel with good corrosion resistance and ability, and can be applied at low and high temperatures [4].

Based on the literature study that has been conducted, different welding procedures may give different outcomes to the results of dissimilar welding joints. In this study, the use of SMAW welding technique in dissimilar welding between AISI 304 and AISI 1018 was carried out by SS and LCS welding procedures which both are different at PWHT stage. Hypothetically, the 
difference in PWHT treatment in the welding procedure gives different characteristics of the welded joint results, this is confirmed through micro structure analysis and joint hardness test. So far, there have been no scientific publications on studies of microstructure analysis and hardness of welded joints of AISI 304 and AISI 1018 with SMAW welding techniques, especially by comparing the use of LCS and SS welding procedures in SMAW technique.

\section{EXPERIMENTAL METHOD}

\section{Materials and Instruments}

The materials used are LCS AISI 1018 (hardness 101.1 HRB) and SS AISI 304 (hardness 78.1 HRB) with the same thickness, which is $10 \mathrm{~mm}$. Electrode AWS A5.4 E308 (diameter $3.2 \mathrm{~mm}$, welding speed $2.5 \mathrm{~mm} / \mathrm{s}, 23.5 \mathrm{~V}$, DCEP polarity, and heat input of $45.12 \mathrm{j} / \mathrm{mm}$ ) from the NIKKO Steel company, as for the chemical composition of the materials at both types of steel and electrodes can be seen in Table 1 below.

Table 1. Chemical composition of materials (\%).

\begin{tabular}{cccc}
\hline Material & AISI 1018 & AISI 304 & E308 \\
\hline $\mathrm{C}$ & 0.174 & 0.076 & 0.08 \\
$\mathrm{Mn}$ & 0.884 & 1.066 & 2 \\
$\mathrm{Si}$ & 0.329 & 0.331 & 0.9 \\
$\mathrm{P}$ & 0.009 & 0.038 & 0.04 \\
$\mathrm{~S}$ & 0.004 & 0.019 & 0.03 \\
$\mathrm{Cr}$ & 0.015 & 18.319 & $18.0-23.0$ \\
$\mathrm{Ni}$ & 0.004 & 7.834 & $9.0-11.0$ \\
$\mathrm{Cu}$ & 0.007 & 0.219 & 0.75 \\
\hline
\end{tabular}

Silicon carbide emery paper (grid 80, 100, 240, $400,600,800,1000,1200,1500$, and 2000), Nital $2 \%$ consisting of $98 \%$ metanol and $2 \% \mathrm{HNO} 3, \mathrm{HCl}$, and distilled water. The chemicals are from Merck with grade pro analysis.

The equipment used in this study consists of SMAW weld-ing machine Derlikon AD 250 WR, Nabertherm furnace for post weld heat treatment (PWHT) process, sandpaper machine Streus Labpol-21, milling machine E KunzmanBelgium, cutting machine Viebahn The MS25, polishing machine Struers Labpol-22, Optical Microscope which is equipped with Image Analyzer Omnimet software to take images of test samples, hardness test machines Rockwell (Zwick/Roell ZHR) to test sample hardness, and others.

\section{SMAW Welding Procedures}

AISI 304 and AISI 1018 are cut to $120 \mathrm{~mm}$ x $40 \mathrm{~mm}$ x $10 \mathrm{~mm}$ and grinded on each side. Then specimen of each steel is created by milling machine each of two pieces. Each side of the specimen is mashed and cleaned with alcohol. The process of dissimilar welding of 2 sets of specimens is carried out in accordance with Welding
Procedure Spesification (WPS). The parameters used as in Table 2 with the merging design scheme diagram shown in Figure 1.

Table 2. Welding parameters with SMAW technique (according to WPS).

\begin{tabular}{ccc}
\hline Welding Parameter & BKR to BKR & BTK to BTK \\
\hline Base Material $(\mathrm{BM})$ & AISI $1018 \mathrm{dan}$ & AISI 1018 dan \\
& AISI 304 & AISI 304 \\
BM Dimension & $240 \times 40 \times 10(\mathrm{~mm})$ & $240 \times 40 \times 10(\mathrm{~mm})$ \\
Weld Position & $1 \mathrm{G}(\mathrm{flat})$ & $1 \mathrm{G}(\mathrm{flat})$ \\
Welding direction & Straight & Straight \\
Preheating & - & - \\
PWHT & - & T $=1000^{\circ} ; \mathrm{t}=12$ menit; \\
& & quenching \\
Electrode & AWS A5.4 E308 & AWS A5.4 E308 \\
& $(\mathrm{d}=3.2 \mathrm{~mm})$ & $(\mathrm{d}=3.2 \mathrm{~mm})$ \\
Weld speed & $2.5 \mathrm{~mm} / \mathrm{s}$ & $2.5 \mathrm{~mm} / \mathrm{s}$ \\
Weld voltage & $23.5 \mathrm{Volt}$ & $23.5 \mathrm{Volt}$ \\
Polarity & DCEP & DCEP \\
Weld current & 80 Ampere & 80 Ampere \\
Heatinput & $45.12 \mathrm{~J} / \mathrm{mm}$ & $45.12 \mathrm{~J} / \mathrm{mm}$ \\
\hline
\end{tabular}

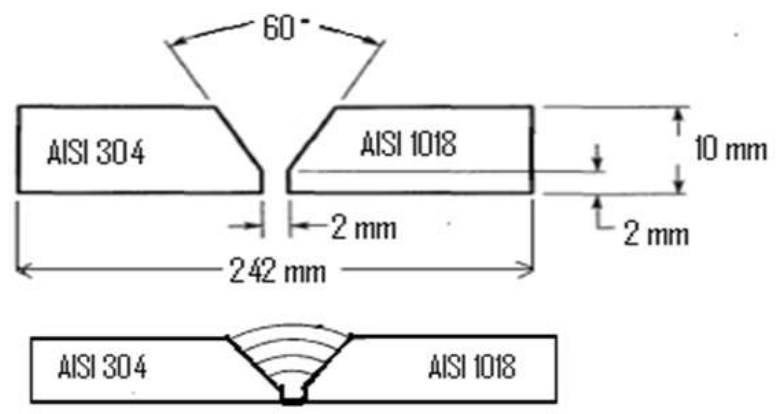

Figure 1. Merging design scheme diagram through SMAW process.

\section{PWHT Procedures}

In this process, for SS-to-LCS welding procedure, a set of welded specimens is heated at a temperature of $1000 \mathrm{oC}$ for 12 minutes at a furnace heating rate of $\pm 9.8 \mathrm{UC} /$ minute. Af-ter that, the specimens are removed and shock cooling is conducted in tap water media.

\section{Metallographic Test}

Metallography was conducted to find the microstructure of both sides of AISI 1018 and AISI 304 and weld metal. For preparation, the weld sample was cut, then sanded using silicon carbide emery paper, polished on a velvet cloth on a polishing machine using toothpaste containing alumina and mixed with water. Then, etching of the specimen was conduct-ed with $2 \%$ nital to bring up the microstructure on the side of low carbon steel and etching aqua regia to bring up the microstructure on the side of stainless steel AISI 304 and weld metal. After preparation, the microstructure was observed using an optical microscope. 


\section{Hardness Test}

This test was conducted to determine the hardness value of the initial specimens and the distribution of hardness in the weld area both on the sides of low carbon steel and stainless steel. The instrument used is a hardness test ma-chine Rockwell B scale which refers to ASTM (American Society for Testing and Materials) E18 standard with a minimum sample thickness of $0.56-1.02 \mathrm{~mm}$ [8].

\section{RESULTS AND DISCUSSION}

Macro photos of the results of dissimilar welding between AISI 304 and AISI 1018 with different procedures can be seen in Figure 2. In Figure 2(a), the welding results of LCS-to-LCS procedure appear that there is a HAZ area in the sides of LCS AISI 1018 so that it does not look homogeneous. This occurs because of the thermal cycle in the area. While on the side of SS AISI 304, the HAZ area is not visible due to the etching process that is not done simultaneously, AISI 304 first then AISI 1018, so that the macro photos on the side of SS AISI 304 are not the actual etching results. In the specimens of welding results with SS-to-SS welding procedure (Figure 2 (b)), the HAZ area on both sides is not visible because of the PWHT process so as to make the microstructure more uniform. However, there are defects in the weld metal section in the form of a smooth hole. The possibility of the formation of this defect can occur due to the release of gas due to differences in the solubility limit between liquid metal and solid metal at freezing temperatures, gas formation due to chemical reactions in the welding metal, and/or gas infiltration into the arc atmosphere. In addition, electrodes that are not preheated can also cause this type of defect.
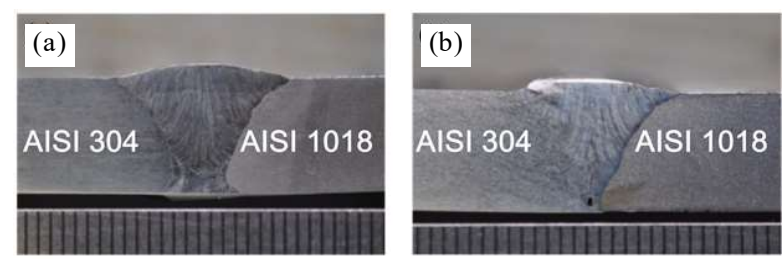

Figure 2. Macro photos of specimens from SMAW welding technique (a) LCS to LCS (b) SS to SS.

In order to find out the effect of welding procedures on the microstructure of the two types of metals, the shape of the microstructure must be known before the welding pro-cess. The microstructure before the process is shown in Fig-ure 3. The microstructure in Figure 3(a) is the microstruc-ture of stainless steel AISI 304 composed of austenite $(\gamma)$ and twin matrices. The twins are annealing twins that are formed due to deformation and are followed by annealing pro-cess when they are made. Whereas in Figure 3(b), the microstructure of BM low carbon steel AISI 1018 consists of
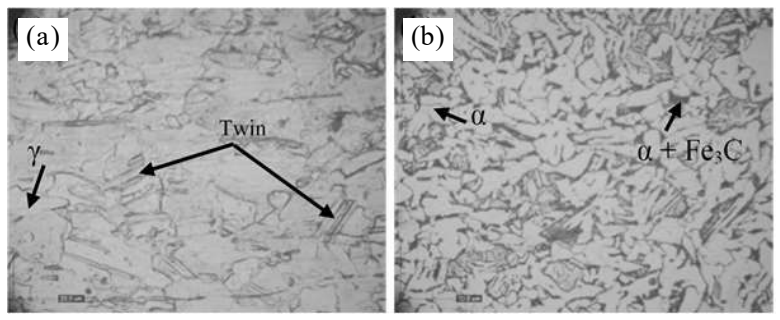

Figure 3. Microstructure of BM, (a) SS AISI 304 (b) LCS AISI 1018 .

two phases namely the ferrite phase $(\alpha)$ which is light colour (white), and the pearlite phase $(\alpha+\mathrm{Fe} 3 \mathrm{C})$ which tends to be dark in colour. The microstructure is commonly found in LCS.

The microstructure of the specimens that have undergone each welding process, LCS to LCS and SS to $\mathrm{SS}$, can be seen in Figure 4. In the area of the side of BM AISI 304, LCS-to-LCS welding results (Figure 4(a)), BM AISI 304/WM - LCS to LCS, there are differences in grain size. Larger grains are HAZ areas while smaller grains are base metal areas or BM AISI 304. Welded LCS is usually in a solution-annealed con-dition or hot rolling, so the heat from welding will result in recrystallization and grain growth which may soften heat-affected areas (HAZ). On the other hand, the formation of the ferrite phase that occurs along the grain boundary of the HAZ will prevent grain growth and cracking on the HAZ. In addition, the ferrite phase was seen in the weld or dilution (FL) boundary area. This happens due to diffusion, be-tween the elements of the weld metal (WM) and the base metal or BM, which is not perfect, resulting in the accumulation of ferrite delta phase at the welding boundary. Whereas in SS-to-SS welding process (Figure 4(b)), BM of AISI 304/WM - SS to SS, the microstructure formed after PWHT is fully aus-tenitic and there are twins. In the WM area, the microstruc-ture of the ferrite delta phase decreases when compared with LCS-to-LCS welding process, this occurs because the ferrite delta phase is dissolved back into the austenite phase during the solidification process [9].

The freezing procedure in LCS-to-LCS procedure results in WM microstructure, WM - LCS to LCS, which is black in color and has a ferrite phase (Figure 4(a)). This phase arises due to the fill metal content, namely $\mathrm{E}$ 308 electrode, having a high $\mathrm{Creq} / \mathrm{Nieq}$ ratio, so generally the solidification formed is the ferrite delta phase. Therefore, during the freezing process, chromium is a forming element in the ferrite phase [10-12]. Conversely, in the WM area - SS to SS area (Figure 4(b)), the structure of the ferrite delta phase is decreasing. It has been mentioned earlier that this occurs because the ferrite delta phase dissolves back into the austenite phase due to PWHT process.

The microstructure on the side of AISI 1018 in LCS-to-LCS process, BM of AISI 1018/WM - LCS to LCS, shows the op-posite phenomenon with BM of AISI 


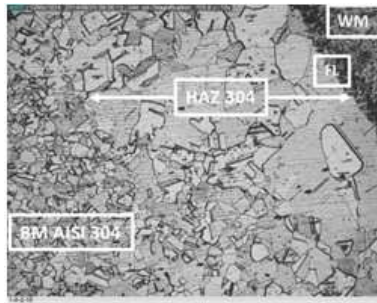

BM 304/WM - BKR ke BKR

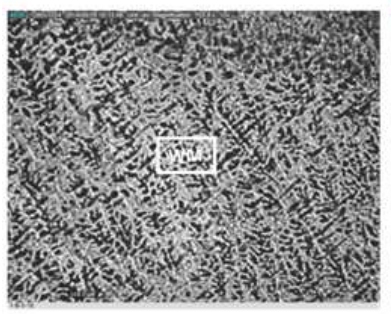

WM - BKR ke BKR

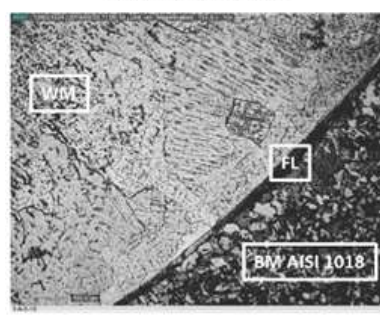

BM 1018/WM - BKR ke BKR

(a)

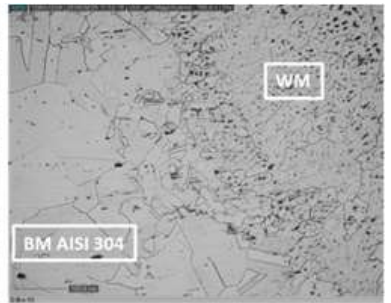

BM 304/WM - BTK ke BTK

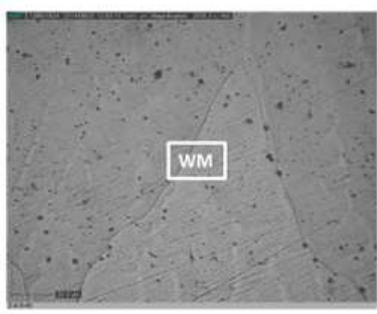

WM - BTK ke BTK

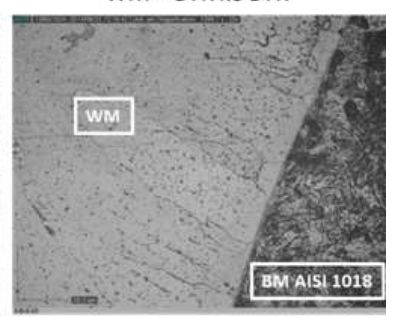

BM 1018/WM-BTK ke BTK

(b)

Figure 4. Microstructure of the results of welding process, (a) LCS to LCS (b) SS to SS

3014/WM - LCS to LCS (Fig-ure 4(a)). The picture shows the occurrence of grain en-largement in the HAZ area, this is due to the heating of the multi-phase welding process. While in the results of SS-to-SS process, on the same side, a fine martensite is formed. This phase is formed due to LCS heating process in the aus-tenite area which is then followed by a high speed cooling process [1].

To find out the possibility of corrosion in the specimen can be seen from the formation of chromium carbide in the weld. The difference between the two processes, LCS to LCS and SS to SS, can be seen in Figure 5.

In Figure 5, with the same magnification, we can see differences in welding results of LCS-to-LCS process and SS-to-SS. The results of welding through LCS-toLCS process form more chromium carbide precipitation when compared with SS-to-SS on the same specimen side. In BM 304/WM - LCS to LCS, black inter-connected precipitates are visible and they occupy grain boundaries on the side of AISI 304. The type of precipitate formed depends on the composition and type of heat treatment, but in general carbide precipitation will form on austenitic stainless steels due to the presence of chromium in large quantities and as a strong carbide forming [12]. Whereas with SS-to-SS process, in AISI 304 , it appears that the precipitate of chromium carbide

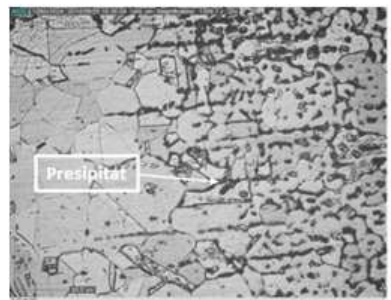

BM 304/WM - BKR ke BKR

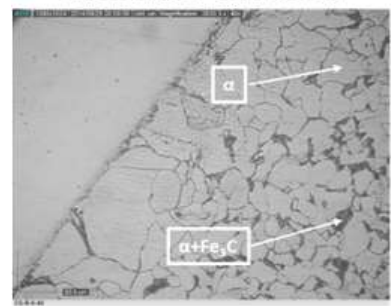

BM 1018/WM - BKR ke BKR

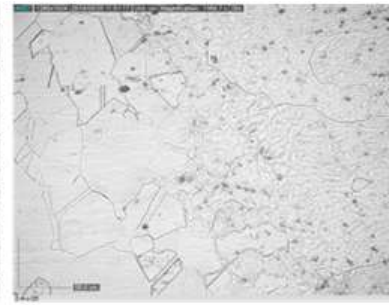

BM 304/WM - BTK ke BTK

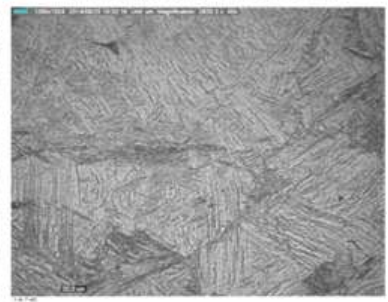

BM 1018/WM - BTK ke BTK

Figure 5. Microstructure of the results of welding process with enlarge images.

is decreasing. This shows that the chromium carbide precipitate is dissolved back into the austenite phase [1]. In addition, high carbon and Ni content in BM and metals can stabilize the austenite phase when cooling from 1100ÚC to room temperature without martensite formation [13].

Similar to the side of AISI 304, the side of AISI 1018 also has differences after undergoing different welding pro-cess. In LCS-to-LCS welding process, multiphase is formed, ferrite and pearlite. Whereas in SS-to-SS process, a fine martensite is formed.

Hardness test of welded specimens uses Rockwell machine with indentation points as shown in Figure 6. Before receiving weld treatment, the hardness value of AISI 1018 samples was $78.1 \pm 0.35 \mathrm{HRB}$ and AISI 304 was $101.1 \pm 1.08$ HRB. After the LCS-to-LCS and SSto-SS welding processes, the results of the hardness test of the two specimens can be seen in Figure 7.

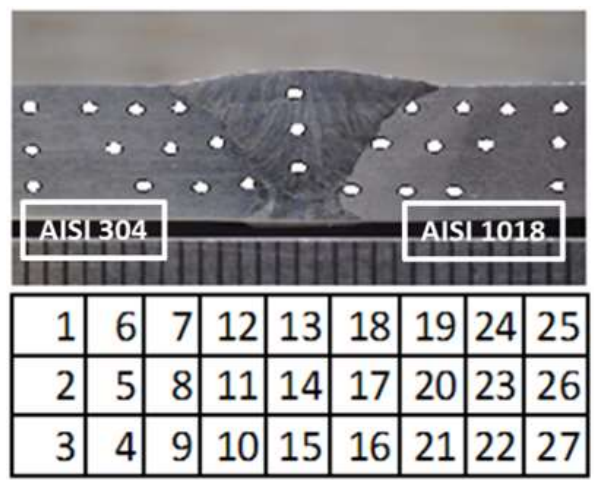

Figure 6. Indentation point of hardness test

From the graph of the distribution of hardness values in the specimens (Figure 7), BM of AISI 304/WM - LCS to LCS, it appears that welding causes a decrease in the hardness value especially in BM/HAZ area (BM 


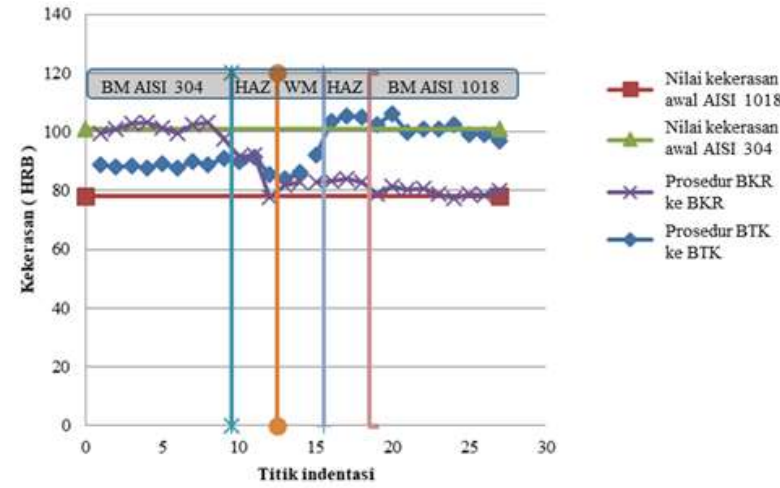

Figure 7. Graph of the distribution of hardness values in the specimens.

approaching HAZ) and the HAZ area, this occurs because of the grain in these areas experiencing enlargement and formed ferrite phase $[9,10]$. Whereas in the BM area of AISI 304, the distribution of the hardness value is not much different from the initial hardness value because the thermal cycle of the welding process does not sufficiently affect the changes in the microstructure of the area.

For WM area, LCS-to-LCS procedure, the hardness is in the range of $81-83 \mathrm{HRB}$. This value is almost the same as welding metal hardness value for electrode $\mathrm{E} 308$ which is $80-82$. On the BM side of AISI 1018 , it appears that the hard-ness value increases in $\mathrm{HAZ}$ area and (BM/HAZ) area. In this, area there is an increase in the hardness value caused by grain coarsening and martensitic phase appears slightly [1].

Whereas from the graph of the distribution of hardness values in SS-to-SS procedure (Figure 7) it can be seen that on the side of AISI 304, BM/HAZ and HAZ, the hardness value decreases when compared to the initial hardness value. When connected with its microstructure, this happens because the grains in the austenite phase are bigger when compared with LCS-toLCS process. In addition, there is the influence of precipitates which dissolve again into the matrix so that the hardness decreases. Ghorbani, S. et al. suggested that the effect of precipitate dissolution can increase tough-ness, which has been known that the relationship of tenacity with hardness is inversely proportional [12]. The heat treatment process at AISI 304 will eliminate distortion and residual tension so that the atoms can diffuse to occupy their balance positions.

For other areas of the specimens with SS-to-SS welding procedure, the specimen hardness value in WM area is rela-tively stable as it still has a ferrite phase. Whereas on the side of low carbon steel AISI 1018, there is an increase in the hardness value in the HAZ area or $\mathrm{BM}$. The formation of fine martensite phase due to the shock cooling is the cause of increased hardness in this area $[6,14]$. It is known that the martensite phase is the phase with the highest hardness value when compared to other phases in carbon steel.
The parameters in this study are very simple, which is following the SMAW WPS technique standard which only compares the effect of PWHT on each specimen. For further research, it may be necessary to change other parameters such as current size, electrode type or welding speed. In addition, it is also necessary to do an Energy-dispersive X-ray spectroscopy (EDS) test to identify precipitation and other mechanical tests, such as tensile tests to determine the strength of the welded joints and impact tests to determine toughness. Studies on the relationship of chromium carbide precipitates to corrosion resistance in welded specimens should also be carried out for further research.

\section{CONCLUSION}

Dissimilar welding between austenitic stainless steel AISI 304 and low carbon steel AISI 1018 using LCSto-LCS welding procedure produces chromium carbide precipitates in the HAZ area of AISI 304 and in the WM area the ferrite phase is formed. With SS-to-SS procedure, not many precipi-tates are formed. This shows the influence of PWHT on the formation of precipitation so that with this procedure the possibility of corrosion can be avoided. The phases formed through this procedure are austenite and twin. In the WM ar-ea, the microstructure of the ferrite delta phase decreases when compared with LCS-to-LCS welding process. The microstructure on the side of AISI 1018 in LCS-to-LCS process oc-curs in grain enlargement in the HAZ area. While the results of SS-to-SS process formed fine martensite.

All welding procedures result in a decrease in the hardness value in the HAZ area of AISI 304. Whereas in the WM area both procedures result in a lower hardness value than BM of AISI 304, SS-to-SS procedure is more stable. Meanwhile, the PWHT process increased hardness in the HAZ/BM area of AISI 1018.

\section{ACKNOWLEDGEMENT}

This research was funded by the 2017 Internal Fund Re-search Program of Institute of Technology and Science Ban-dung.

\section{REFERENCE}

[1]. P. M P and G. R. Kannan, Optimization of laser welding process parameters in dissimilar joint of stainless steel AISI316/AISI1018 low carbon steel to attain the maximum level of mechanical properties through PWHT. 2018, pp. 314-322.

[2]. W. Chuaiphan, C. Ambhorn Somrerk, S. Niltawach, and B. Sornil, Dissimilar welding between AISI 304 stainless steel and AISI 1020 carbon steel plates. 2012,pp. 283-290.

[3]. S. Suwarno and A. Sahab, Prediksi Derajad Presipitasi Karbida Krom pada Baja Tahan Karat 
Austenitik dengan Metode Jaringan Syaraf Tiruan. 2004.

[4]. J. C. Lippold and D. J. Kotecki, "Welding metallurgy and weldability of stainless steels," (in English.), 2005.

[5]. L. Griffing, Metals and their weldability. [Miami]: American welding Society (in English), 1972.

[6]. W. Wu, S. Hu, and J. Shen, "Microstructure, mechanical properties and corrosion behavior of laser welded dissimilar joints between ferritic stainless steel and carbon steel," Materials \& Design (1980-2015), vol. 65, pp. 855-861, 2015/01/ 01/ 2015, doi: https://doi.org/10.1016/ j.matdes.2014.09.064.

[7]. S. Kou, "Welding metallurgy," (in English), 2010.

[8]. "ASTM E18-15, Standard Test Methods for Rockwell Hardness of Metallic Materials," ed. West Conshohocken, PA: ASTM International, 2015.

[9]. M. F. Buchely, H. A. Colorado, and H. E. Jaramillo, "Effect of SMAW manufacturing process in highcycle fatigue of AISI 304 base metal using AISI 308L filler metal," Journal of Manufacturing Processes, vol. 20, pp. 181-189, 2015/10/01/2015, doi: https://doi.org/10.1016/j.jmapro.2015.08.005.

[10]. R. Unnikrishnan et al., "Effect of heat input on the microstructure, residual stresses and corrosion resistance of 304L austenitic stainless steel weldments," Materials Characterization, vol. 93, pp. 10-23, 2014/07/01/ 2014, doi: https://doi.org/ 10.1016/j.matchar.2014.03.013.
[11]. A. Y. Jang, D. J. Lee, S. H. Lee, J. H. Shim, S. W. Kang, and H. W. Lee, "Effect of $\mathrm{Cr} / \mathrm{Ni}$ equivalent ratio on ductility-dip cracking in AISI 316L weld metals," Materials \& Design, vol. 32, no. 1, pp. 371-376, 2011/01/01/ 2011, doi: https://doi.org/ 10.1016/j.matdes.2010.06.016.

[12]. S. Ghorbani, R. Ghasemi, R. Ebrahimi-Kahrizsangi, and A. Hojjati-Najafabadi, "Effect of post weld heat treatment (PWHT) on the microstructure, mechanical properties, and corrosion resistance of dissimilar stainless steels," Materials Science and Engineering: A, vol. 688, pp. 470-479, 2017/03/14/ 2017, doi: https://doi.org/10.1016/ j.msea.2017.02.020.

[13]. M. Gruber, G. Ressel, F. Méndez Martín, S. Ploberger, S. Marsoner, and R. Ebner, "Formation and Growth Kinetics of Reverted Austenite During Tempering of a High Co-Ni Steel," Metallurgical and Materials Transactions A, vol. 47, no. 12, pp. 5932-5941, 2016/ 12/01 2016, doi: 10.1007/s11661-016-3760-8.

[14]. M. R. A. Shawon, F. Gulshan, and A. S. W. Kurny, "Effect of Welding Current on the Structure and Properties of Resistance Spot Welded Dissimilar (Austenitic Stainless Steel and Low Carbon Steel) Metal Joints," Journal of The Institution of Engineers (India): Series D, vol. 96, no. 1, pp. 29-36, 2015/04/01 2015, doi: 10.1007/s40033-0140060-6. 